\title{
Irrigation And Risk Of Saline Pollution. Example: Groundwater Of Annaba Plain (North East Of Algeria)
}

\author{
Halimi Samia, MA \\ Department of Ecology, University of Khenchela, Algeria \\ Department of Geology, University of Annaba, Algeria \\ Baali Fethi, Dr \\ Department of Geology, University of Tébessa, Algeria \\ Kherici Nacer, Pr. \\ Department of Geology, University of Annaba, Algeria \\ Zairi El moncef, $\mathrm{Pr}$ \\ École national des ingénieurs, Tunisie \\ Bouhsina Saad, Pr \\ Université du Littoral Côte d'Opale, Dunkerque, France
}

doi: 10.19044/esj.2016.v12n6p241 URL:http://dx.doi.org/10.19044/esj.2016.v12n6p241

\begin{abstract}
In the Annaba plain (Northeast of Algeria), the anthropogenic activities have imposed serious unfavorable impacts on hydraulic, hydrochemical and biological balances that influence the socio-economic future of this area. A hydrochemical analysis was performed in 29 wells distributed over the whole of the plain region during the period of high water (December 2013) to assess the quality of groundwater for its suitability for irrigation. Several parameters were analyzed such as $\mathrm{pH}$, TDS, $\mathrm{Ca}^{+2}, \mathrm{Mg}^{+2}$, $\mathrm{Na}^{+}, \mathrm{K}^{+}, \mathrm{HCO}_{3}{ }^{-}, \mathrm{Cl}^{-}$and $\mathrm{SO}_{4}{ }^{-}$. Analysis of results suggests that groundwater in the study area has the same qualities; however the observed degradation reflects a change in the water quality, and the SAR values vary from 0.08 to 16 with an average of 1.3. The US salinity laboratory, Wilcox, and percentage $\mathrm{Na}+$ it suggest that the majority of groundwater samples are not good for irrigation.
\end{abstract}

Keywords: Annaba Plain, Algeria, Groundwater, Irrigation, Salinization

\section{Introduction:}

In the wake of global warming and its associated changes in environmental conditions, the surface water availability becomes restricted 
and inadequate to meet all the water requirements for all purposes. Therefore, the demand for groundwater has increased over the years. However, the chemical composition of water is an important factor to be considered before it is used for domestic, irrigation or industrial purposes (Suresh et al., 1991).

In the low plain of Seybouse, the chemical composition of water is often influenced by the impact of the dissolution of geological formations, industrial discharges, and agricultural activities (Kherici 1993, Djabri 1996, Hani 2003, Zenati 2010, Habes 2013). Thus, it is required to periodically check the water quality changes over time and space depending on the variation of the physicochemical parameters of the water. To achieve these goals, it is important to make a monthly monitoring of water (surface and groundwater), with a comprehensive analysis of physicochemical parameters to explain the origin and evolution of each element (Rouabhia et al., 2010).

\section{Geographic Location}

The Annaba plain is situated in the northeastern part of Algeria (Fig.1).

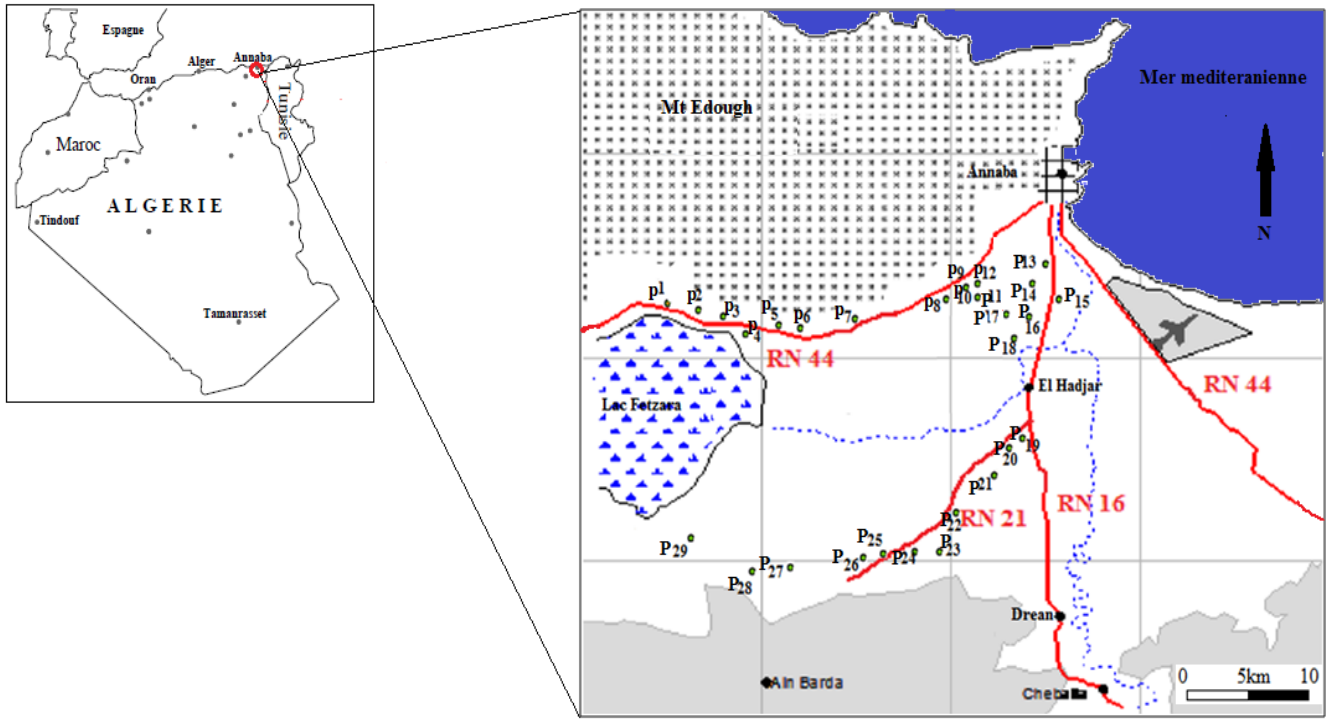

Fig. 1: Location map of the study area in Eastern Algeria

The area is subject to a Mediterranean climate defined by a cold and rainy winter and a hot, dry summer. The average annual rainfall, actual evapotranspiration and recharge are respectively 700, 500 and $80 \mathrm{~mm}$.

\section{Geological and hydro geological Framework}

The region of Annaba has been the subject of several geological studies, including that of Joleaud (1936), Hilly (1936), Vila (1980), Lahondère (1987) and Laouar et al. (2002). These studies indicate the existence of two 
types of courses, one sedimentary and the other one metamorphic (Fig. 2). The stratigraphic column of this land is distributed from Primary to Quaternary:

1) Primary pedestal: is flush on the west in the Massif of Edough, Belelieta and Bouhamra, cristallophylliennes rocks formed by that are superimposed in three series:

$>$ Lower series: represented by wealthy biotite gneiss and sillimanite with an average thickness of $70 \mathrm{~m}$, this training constitutes the heart of the anticline Edough Massif.

$>$ Intermediary Series: characterized by schists and micarich biotite, muscovite and garnet and sometimes with feldspaths often visible to the naked eye. This series contains Marble who intercalate into the formations of mica skarns form;

$>$ Upper series: constituted by a set of visible gneiss, satiny schist, mica schist and amphibolites garnet. These three series are the low viewpoint of the hydrogeological, except for the altered gneiss or fractured cipolin that can constitute the headquarters of an underground water table.

2) The secondary Plinth is flush apart from the study region, in the southern part, at the level of the region of Guelma and Bouchegouf, 20-50 km south of the study area. The three systems are constituted by:

$>$ The Triassic: formed by an association of dolomitic limestone and gypsum;

The Jurassic represented by black shale and limestone dolomite;

The Cretaceous includes dolomitic limestones rich in foraminifera and rudest debris.

3) The Tertiary Plinth presents an important thickness in the study area with three systems:

$>\quad$ The Lower Eocene: transgressive series formed of solid limestone facies;

$>$ The oligocene include clay levels Numidian sandstones which form the relief of mountains of southern plain of Annaba, its thickness reaches $150 \mathrm{~m}$;

$>$ The Mio-Pliocene constitutes gravelly and clayey sand filling in the basin of the Annaba plain. These trainings are of continental origin, they include gravel and travertine levels that constitute the gravel tablecloth 


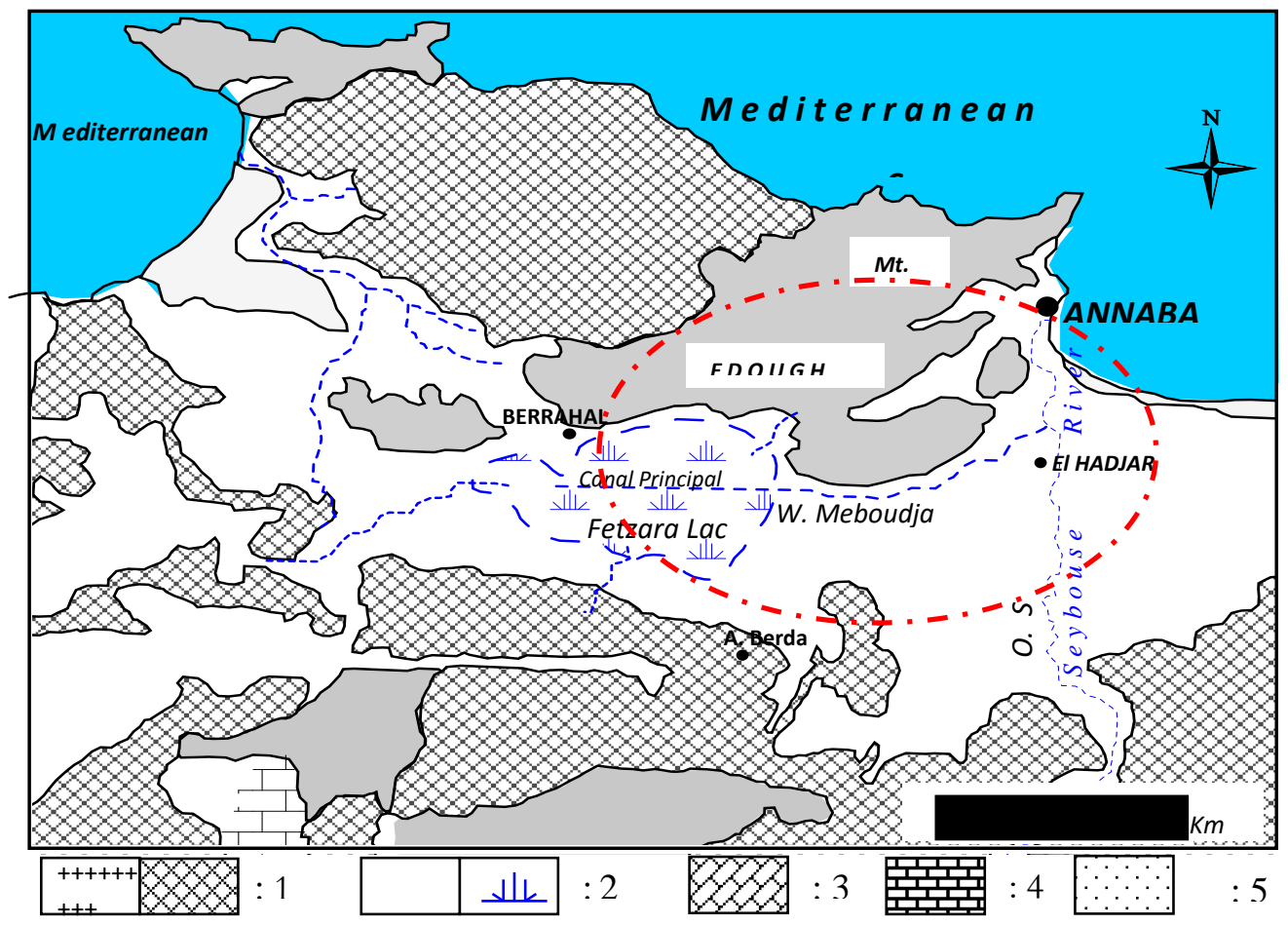

1: Metamorphic formation (Gneiss, Micaschists). 2: Undifferentiated Quaternary (Dunes and Ancient alluvium), lake or swamp. 3: Flyschs. 4: Numidian sandstone or clay. 5: dunes.

Fig. 2 : Geological map of the study area (Rouabhia, 1993).

4) The quaternary, three levels are dustings:

$>$ The former Quaternary constituted by alluvial formations (clay, silt, sand, gravel and pebbles) constituting the high terrace, its altitude varies between 75 and $150 \mathrm{~m}$;

$>$ Average quaternary corresponds to the lower terrace 20 to $50 \mathrm{~m}$, constituted by clays and sands. It supports the cultivated land. This terrace develops on the entire Area mainly at the level of the valley of Wadi Seybouse;

$>$ The recent quaternary corresponding to sand dune ridges and alluvial silts of Seybouse.

Formations highlight two aquifers (Fig. 3) linked principally by the Wadi Meboudja, as well as by the superficial aquifer of Annaba (NSA) and by the alluvial aquifer of the higher terraces, the second aquifer is fed by the first using the connection of the Meboudja wadi (Habes, 2006). The saturated thickness of the unconfined aquifer can reach $18 \mathrm{~m}$ at the south of Annaba. This aquifer is tapped by drillings and wells. 


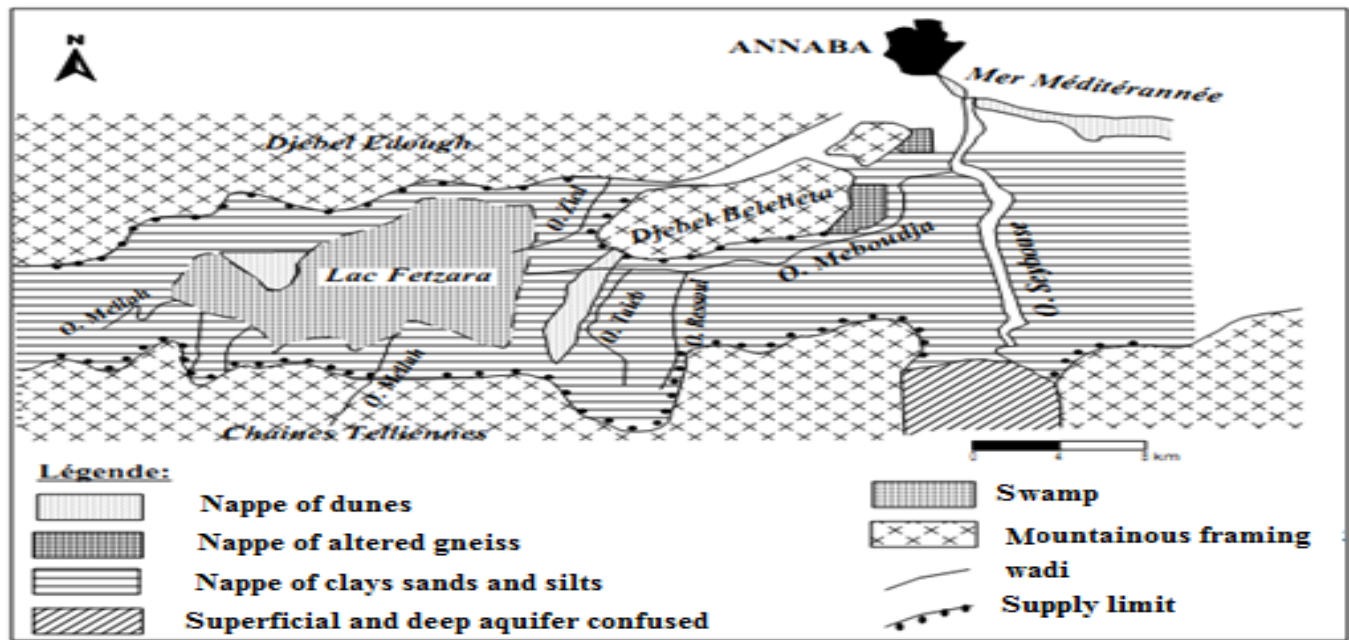

Fig. 3: Location of the superficial layers in the plain of Annaba (Habes, 2006)

The hydraulic head measurements taken between the $5^{\text {th }}$ and $10^{\text {th }}$ of February 2010 on 70 levelled domestic wells were plotted on an elaborate piezometric map by the kriging interpolation method using surfer 0.8 . Flow follows the topographic form of the studied zone in a south-north direction. However, at the level of the Daghoussa hillock, there is a change of direction from the sea towards the continent.

The piezometric interpretations (Fig. 4) show the interaction between the lake, wadi, and aquifer systems. Excessive pumping (more than 100 installations) in the studied zone affects both the superficial and deep aquifers and generates a change of flow direction. The rate of flow of the extracted water is about ( $26.2 \mathrm{~mm}^{3} /$ year).

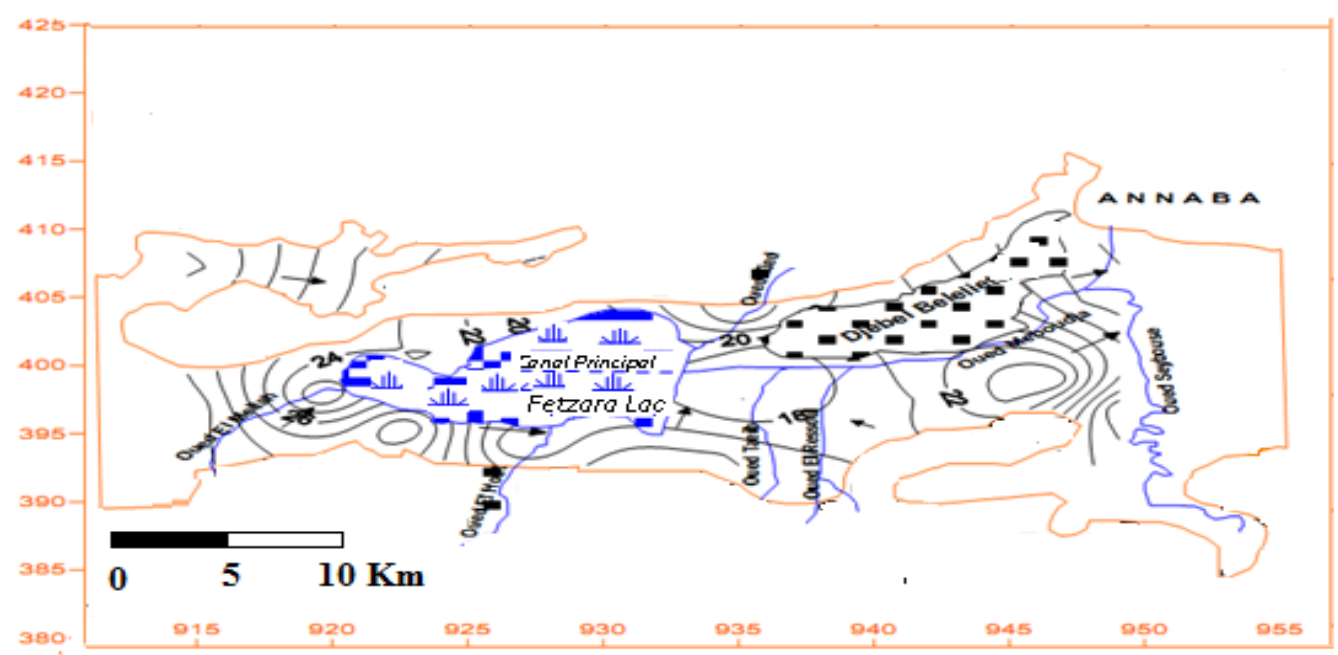

Fig. 4 : Potentiometric map of the study area (Zenati, 2010) 
The water level of the superficial aquifer has lowered from 3 to $5 \mathrm{~m}$. The recharge is dependent on precipitation (Djabri et al., 2003), (Zenati, 2010). Increased pumping and reduced recharge generates an imbalance of the saltfresh water interface, resulting in increased salinity.

\section{Materials and methods}

The hydrochimical properties of groundwater samples collected from the quaternary aquifer system are shown in Table 1. The sites which samples were taken are show en in Fig 1 . The physiochemical parameters $\left(\mathrm{pH}, \mathrm{T}^{\circ} \mathrm{C}\right.$, and conductivity) were measured in situ using a WTW multi-parameter device (Multi-line P3 PH/LF-SET). The piezometric level was measured with a SEBA KLL probe for the measurement. The chemical analysis was carried out by flame atomic absorption (Perkin-Elmer 11005) for Cations. Anions $\mathrm{Cl}^{-}, \mathrm{SO}_{4}{ }^{2-}, \mathrm{HCO}_{3}$ were measured using a CPM. These elements were measured in the Hydrochimical Laboratory of University of Littoral Côte d'Opale, Dunkerque on (France).

\section{Results and discussion}

\section{Identification of chemical facies water}

Table.1 shows the variability and magnitude of different physicochemical parameters of groundwater across the whole sector studied.

Table.1 Basic statistics of the various physicochemical parameters measured (December

\begin{tabular}{cccccc}
\hline Parameters & Units & Min & Max & Average & Standard deviation \\
\hline $\mathrm{CE}$ & $(\mathrm{MS} / \mathrm{cm})$ & 2,07 & 9,68 & 5,87 & 3,81 \\
$\mathrm{~T}$ & $\left({ }^{\circ} \mathrm{C}\right)$ & 14 & 18,10 & 16,05 & 2,05 \\
$\mathrm{pH}$ & & 6,53 & 6,95 & 6,740 & 0,21 \\
$\mathrm{Cl}-$ & $\left(\mathrm{mg} . \mathrm{l}^{-1}\right)$ & 5 & 350 & 177,50 & 1,30 \\
$\mathrm{SO}_{4}^{-2}$ & $\left(\mathrm{mg} . \mathrm{l}^{-1}\right)$ & 25 & 136 & 80,50 & 0,93 \\
$\mathrm{HCO}_{3}{ }^{-}$ & $\left(\mathrm{mg} . \mathrm{l}^{-1}\right)$ & 2,20 & 52,40 & 27,30 & 0,77 \\
$\mathrm{Ca}^{+2}$ & $\left(\mathrm{mg} . \mathrm{l}^{-1}\right)$ & 0,40 & 30 & 15,20 & 1,28 \\
$\mathrm{Na}^{+}$ & $\left(\mathrm{mg} . \mathrm{l}^{-1}\right)$ & 15 & 200 & 107,50 & 1,17 \\
$\mathrm{~K}^{+}$ & $\left(\mathrm{mg} . \mathrm{l}^{-1}\right)$ & 2 & 13,70 & 7,85 & 1,09 \\
$\mathrm{Mg}^{+2}$ & $\left(\mathrm{mg} . \mathrm{l}^{-1}\right)$ & 20 & 120 & 70,00 & 1,03 \\
$\mathrm{TDS}^{+1}$ & $\left(\mathrm{mg} . \mathrm{l}^{-1}\right)$ & 192 & 854 & 523 & 331 \\
$\mathrm{Sal}^{-1}$ & $\left(\mathrm{mg} . \mathrm{l}^{-1}\right)$ & 0,60 & 5,40 & 3,00 & 2,40 \\
$\mathrm{RS}^{-1}$ & $\left(\mathrm{mg} . \mathrm{l}^{-1}\right)$ & 144,9 & 1391,6 & 383,12 & 264,41 \\
$\mathrm{NO}_{2}^{-}$ & $\left(\mathrm{mg} . \mathrm{l}^{-1}\right)$ & 30 & 130 & 80 & 91,92 \\
$\mathrm{NO}_{3}^{-}$ & $\left(\mathrm{mg} . \mathrm{l}^{-1}\right)$ & 11 & 94 & 52,5 & 58,68 \\
\hline
\end{tabular}

The allocation of the anions for this period (December 2013) highlights a different dynamic from other periods. This reflects is the acquisition mode 
(dominant) of chemistry: chlorides and sulfates have relatively high levels (Fig. 5a, b). The cations are the same scenario, magnesium and sodium dominate. The Previous table also confirms the impact of geology on the water quality; bicarbonates derived boundary formations, while the sulfates and chlorides are related to human activities.

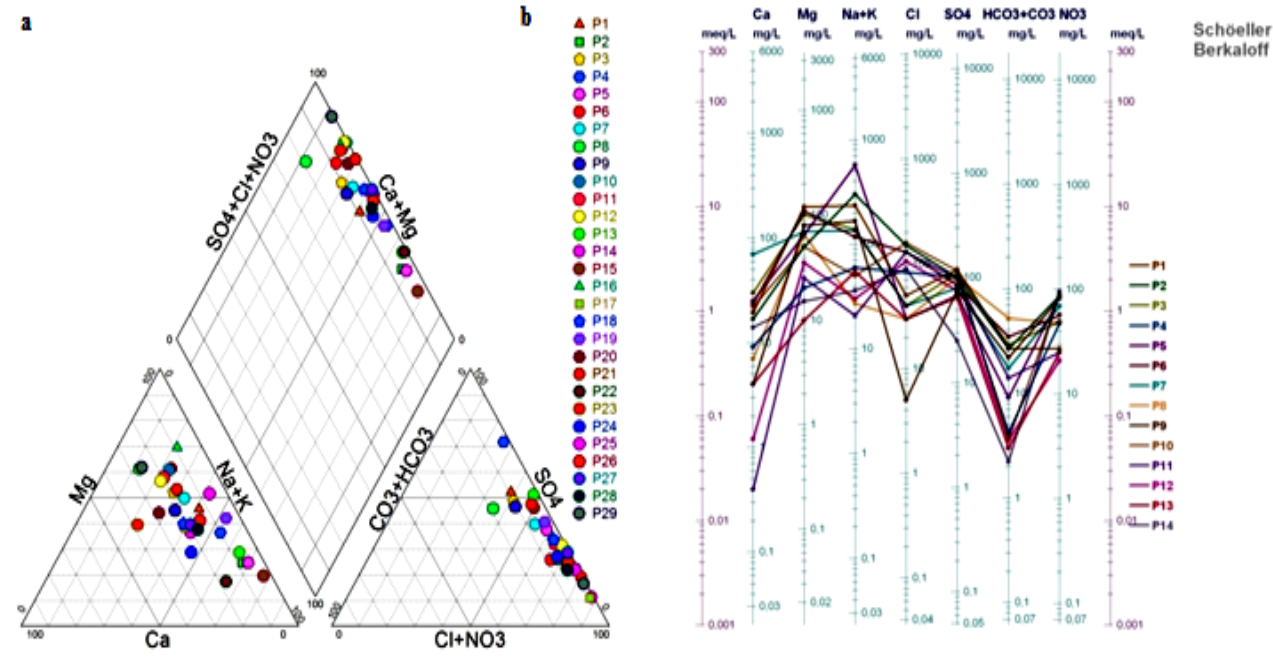

Fig.5 Identification of chemical facies water in the study area (a Piper, b Schoeller Berkallof)

\section{Ionic relationship and sources of major components}

The dissolved chemical species and their relationships with each other may reveal the origin of elements and the processes of the observed groundwater composition. The statistical analyzes indicate a positive correlation between some pairs of parameters shown in (Fig. 6).

The report of $\mathrm{Na}^{+}-\mathrm{Cl}^{-}$shows an excess of chloride $\left(\mathrm{Cl}^{-}\right)$can be explained by the existence of different origins that increase the concentration of the latter relative to that of sodium. These excess chlorides may come from the dissolution of salts, infiltration of wastewater and recycled water for irrigation. As the chloride excess is accompanied by a sodium deficiency, it can be explained by the Base Exchange associated with clay minerals, which fix $\mathrm{Na}^{+}$ion after the liberation of $\mathrm{Ca}^{2+}$ (Fig. 6a).

The relation between $\mathrm{Mg}^{2+}$ and Cl- shows an enrichment of approximately $50 \%$ of the groundwater samples to the mixing line. Such enrichment may be due to the dissolution of the dolomite of reservoir rock (Fig. 6b). 

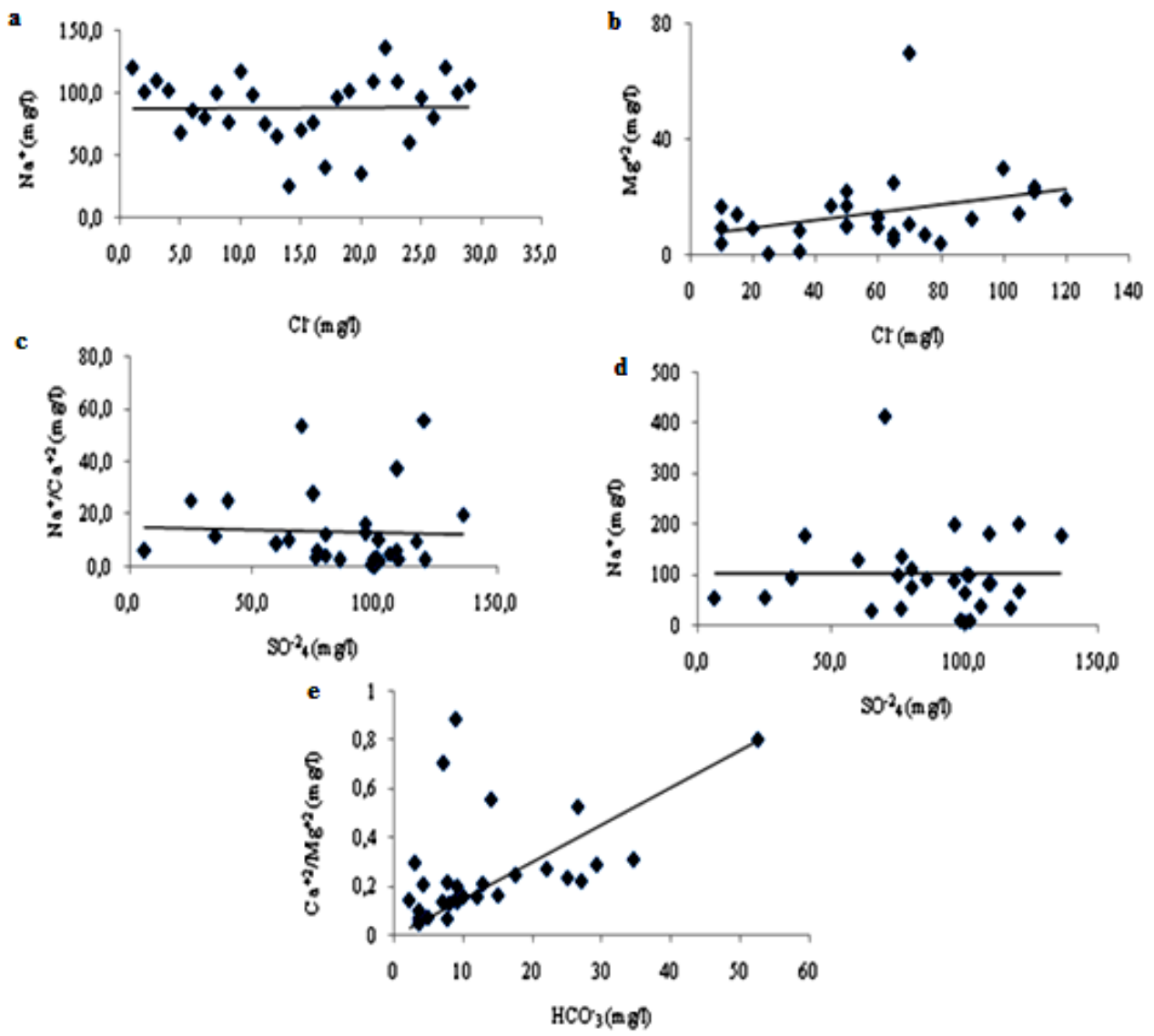

Fig. 6 Relation between elements: (a) Cl vs. Na, (b) $\mathrm{Cl}$ vs. $\mathrm{Mg}^{+2}$, (c) $\mathrm{SO}_{4}{ }^{-2} \mathrm{vs} \mathrm{Na}^{+} / \mathrm{Ca}^{+2}$, (d) $\mathrm{SO}^{-2}$ vs. $\mathrm{Na}^{+}$, (e) $\mathrm{HCO}_{3}^{-}$vs. $\mathrm{Ca}^{+2} / \mathrm{Mg}^{+2}$.

The Graphics $\left(\mathrm{Na}^{+} / \mathrm{Ca}^{+2}-\mathrm{SO}_{4}^{-2}\right.$ and $\left.\mathrm{Na}^{+}-\mathrm{SO}_{4}^{-2}\right)$ show an excess of $\mathrm{s}$ sulphate mainly due to the alteration of calcium sulphate and magnesium (evaporates and pyrite) on one hand and human activities on the other hand (use of chemical fertilizers). Lower concentrations of $\mathrm{Na}^{+}$ions are due to the Base Exchange (Fig. 6c, 6d).

The relation between $\mathrm{Ca}^{+2} / \mathrm{Mg}^{+2}$ versus $\mathrm{HCO}_{3}{ }^{-}$(Fig. 6e) shows an excess of bicarbonate, which can be explained either by feeding by waters rich in carbonates from the border or the drainage of water from the deep aquifer (long time stay ensures the dissolution of carbonate formations). 


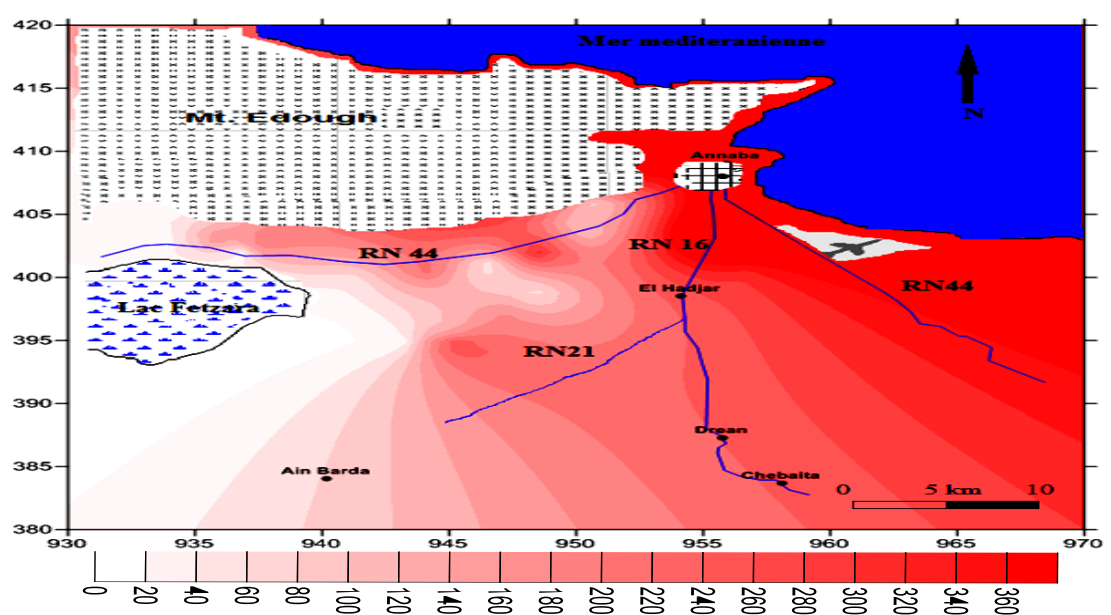

Fig.7 : Chloride distribution in the water plain of Annaba (December 2013)

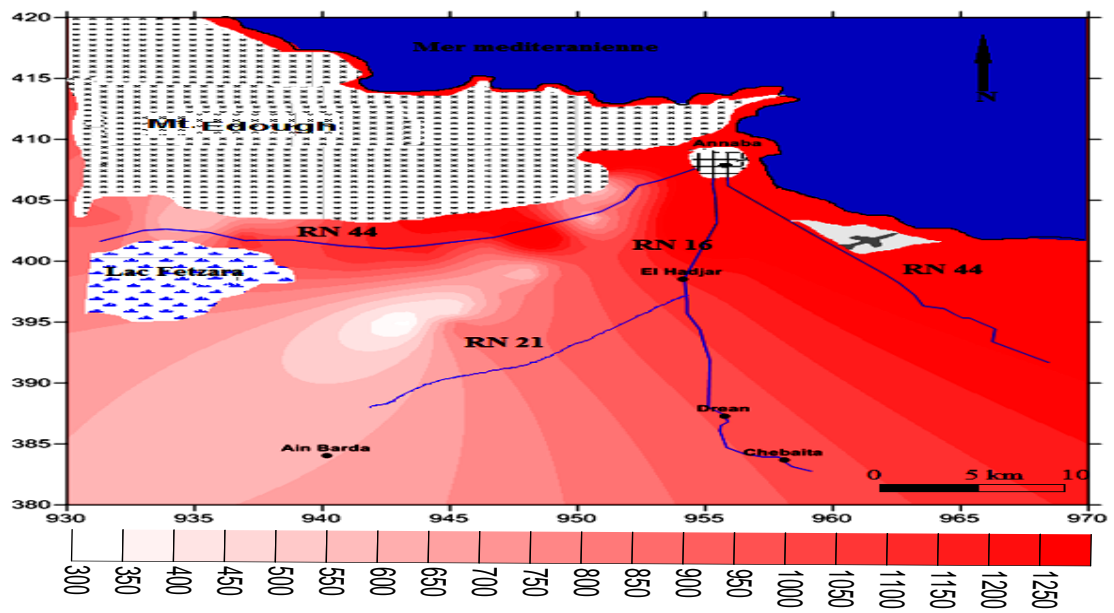

Fig.8 : TDS distribution in the water plain of Annaba (December 2013)

\section{Saturation index}

To assess the geochemical processes responsible for the mineralization of groundwater in the Annaba plain, particular attention is paid to the chemical composition, the saturation index (SI) of water with respect of certain minerals. The saturation index expresses the degree of balance between chemical and mineral water in the aquifer matrix considered a measure of the process of dissolution and/or precipitation on water-rock interaction (Drever, 1997). The use of geochemical program PHREEQC (Plummer et al., 1976), allowed us to calculate the saturation index with respect to anhydrite, aragonite, calcite, dolomite, gypsum (Fig. 9 and 10). 

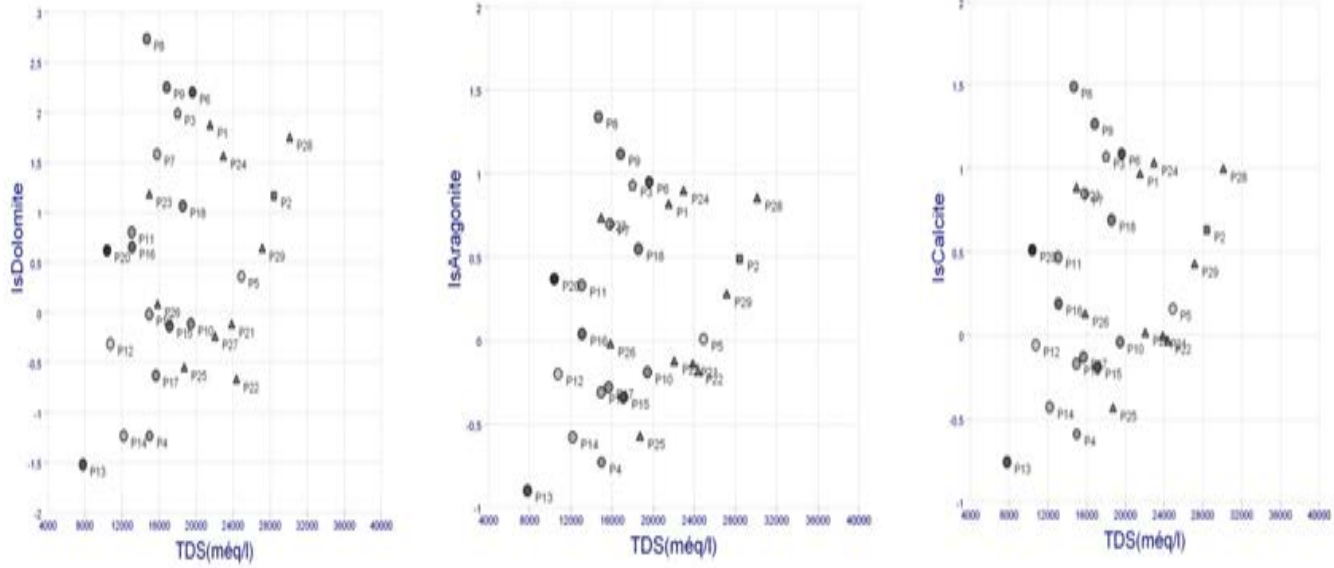

Fig. 9: Relationship saturation indices carbonate minerals with total meniralization groundwater in the plain of Annaba (December 2013).
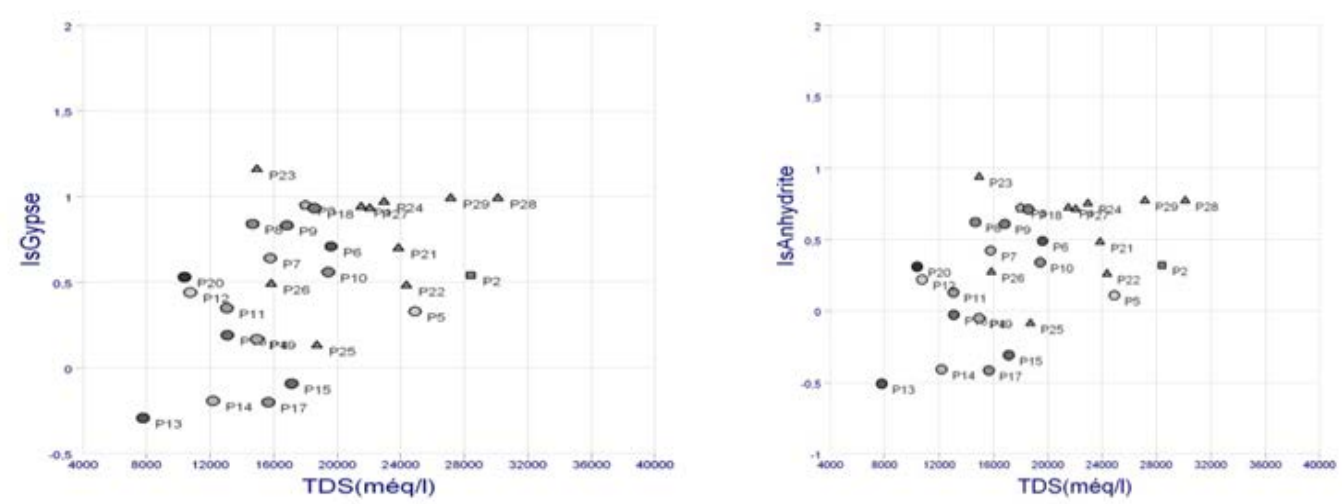

Fig.10 : Relationship saturation indices evaporate minerals with total meniralization groundwater in the plain of Annaba (December 2013).

The calculated index of minerals in water saturation indicates that only carbonate minerals tend to precipitate particularly in the form of dolomite.

The relationship between the saturation index and the carbonate minerals (Fig. 9) shows that most of the waters are over saturated with calcite, aragonite and dolomite. Indeed, the relationship between the saturation indices of evaporated minerals and the TDS shows that the waters of the plain are almost in balance with minerals evaporate : gypsum and anhydrite (Fig.10). 


\section{Irrigation water quality}

In this study, we will highlight the use of water for irrigation of agricultural land in the Annaba plain (December 2013). The methods of Richards (1954) and Wilcox (1948) are still the most frequently used.

\section{Risk of sodicity and salinity}

The major factors that degrade the quality of water for irrigation are therefore summarized to the concentration of dissolved salts, expressed by the dry residue or the electrical conductivity, the potential salinity, the sodium concentration and the relating quantity of toxic elements (boron and chlorine) in the water. This is linked to the dry residue (RS) and the osmotic pressure $\pi$ calculated by the following formulas:

$R S(\mathrm{mg} / \mathrm{l})=0.7 \mathrm{CE}(\mu \mathrm{S} / \mathrm{cm})$ $\pi(\mathrm{atm})=0.00036 . \mathrm{CE}$

The soil salinity is constituted by all the salts, particularly sodium chloride, magnesium and sulphates (Doneen, 1961). Therefore, the potential salinity (Sp) can be estimated by:

$$
\mathrm{SP}=\mathrm{Cl}+1 / \mathrm{SO}_{4}{ }^{-2}
$$

It was acknowledged that the concentration of sodium in the irrigation water has an influence on the permeability and infiltration of the soil (harmful effects on soil structure through the clay flocculating). This effect is interpreted by different authors by calculating several parameters such as the SAR previously mentioned:

$$
S A R=\frac{N a}{\sqrt{\frac{C a+M g}{z}}}
$$

The sodium percentage ( $\mathrm{Na} \%$ ) is calculated using the formula given below, were all the concentrations are expressed in miliequivalents per liter:

$$
\mathrm{Na} \%=\frac{\mathrm{Na}+\mathrm{K}}{(\mathrm{Ca}+\mathrm{Mg}+\mathrm{Na}+\mathrm{K})} * 100
$$

These parameters can act separately or combined to the classification of irrigation water, four classes appear excellent, good, poor and permissible.

The groundwater in the study area have the same qualities, the observed degradation reflects a change in the water quality. 

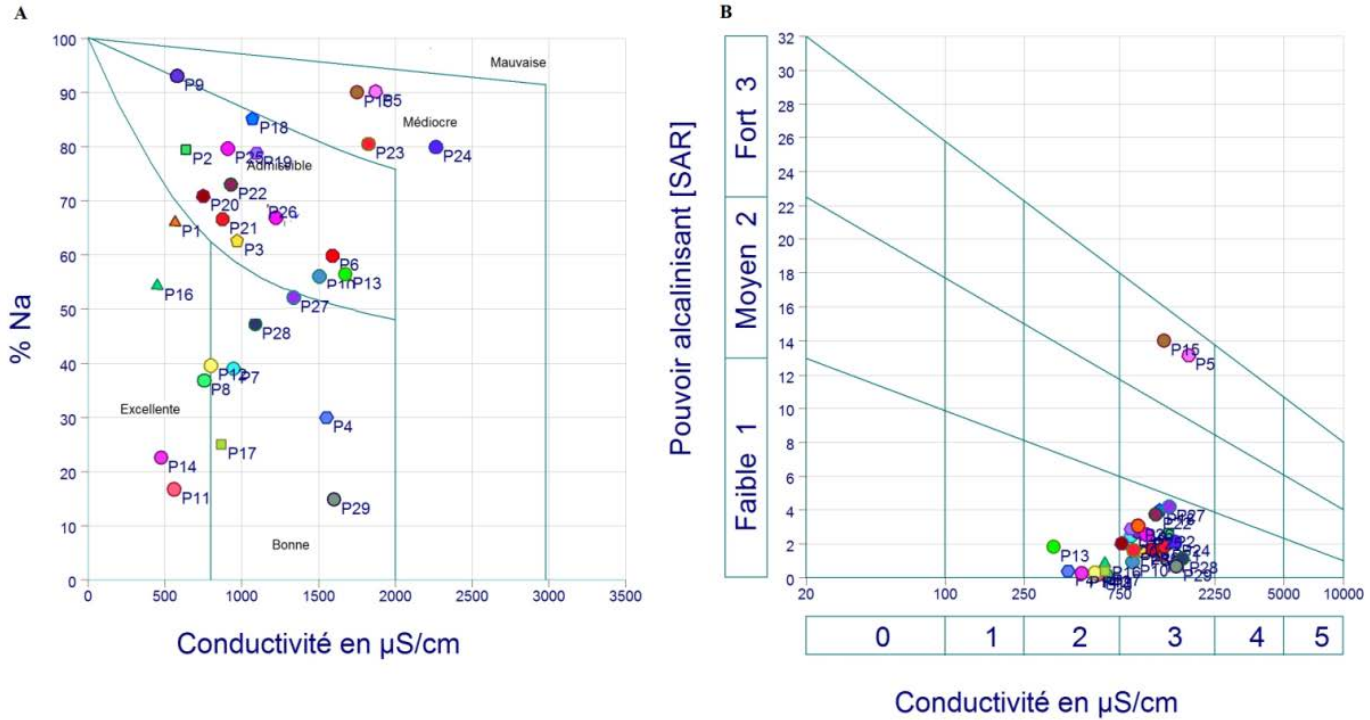

Fig. 11: Classification of irrigation water in the study area, (a) USA Salinity Laboratory diagram, (b) Wilcox (1948).

The representation of the conductivity and the SAR on a US salinity pattern (Fig. 11B) shows that the majority of samples are located in two classes of water: the categories C2S1 (medium salinity and low alkalinity) and C3S1 (high salinity and low alkalinity). Both categories fall in the suitable class for agriculture purposes. Two samples 5 and 15 fall in the poor zone of water quality (C3S3) so the water is unusable for agriculture.

The Wilcox diagram (Fig.11A), relating sodium percentage, and electrical conductivity, shows that most of the groundwater samples fall in the category of good to permissible. $50 \%$ of samples fall in permissible to the doubtful category, sample numbers: 5, 9, 15, 23, 24 and 25 are in the doubtful category improper for irrigation, suggesting the involvement of human activities.

\section{Conclusion}

The underground water of the aquifer of Annaba introduces important variations of the mineralization, which becomes more marked, with the sense of flow. Conductivity is generally high and wobbles between $2.07 \mathrm{mS} / \mathrm{cm}$ and $9.67 \mathrm{mS} / \mathrm{cm}$. The most charged zones are in direct link with Sorted him Out sulfurous. This salinity is particularly controlled by chlorides and sodium. The use of major and minor chemical elements allowed us to understand the process of normalization of water. Therefore, this mineralization comes from the dissolution-precipitation of the aquifer rock, evaporation and the Base Exchange. 


\section{References:}

Debieche. H: Evolution de la qualité des eaux (salinité et métaux lourds) sous l'effet de la pollution saline, agricole et industrielle .Application à la basse plaine de la Seybouse- Nord - Est Algérien. Thèse de doctorat de l'université de Franche Comte ; 235 p, 2002.

Djabri. L: Mechanism of Seybouse water pollution and vulnerabilitygeological, industrial, agricultural and urban origins. Doctorat Thesis, University of Annaba, 176 p, 1996.

Fehdi. C et al: Caractérisation hydrogéochimique des eaux souterraines du complexe aquifère Morsott-Laouinet (Région Nord de Tébessa, Sud-Est algérien). Afrique SCIENCE 05(2) (2009) 217 - 231 ISSN 1813-548X, 2009.

Habert .P: Eaupuscul, une introduction à la gestion de l'eau, $2^{\text {émme }}$ édition HGA, Buresti, Romania ; 209 p, 1998.

Habes .S: Caractéristiques chimiques d'un lac appartenant aux écosystèmes humides du Nord de l'Algérie; Cas : Lac Fetzara Nord - Est Algérien. Université Annaba, 168 P, 2013.

Habes. S. et al : Quantification des apports et des exores d'un lac : cas du lac Fetzara, région de Annaba (Nord-Est Algérien). Revue des Sciences et de la Technologie-Synthèse, №24 (04/2012), pp. 21-28, 2012.

Hani. A: Methodological examination of anthropological structure and process, application for Mediterranean coastal basin. Doctorate These, Annaba University, 213 p, 2003.

Hilly J.: Etude géologique du massif de l'Edough et du Cap de Fer (EstConstantinois). Publications du Service de la Carte Géologique e l’Algérie. Bulletin N¹9, 408 P, 1962.

Kherici. N : Vulnérabilité à la pollution chimique des eaux souterraines d'un système de nappes superposées en milieu industriel et agricole (Annaba-la Mafragh), Nord-Est Algérien. Th. Doctorat. Es-Sciences, Université d'Annaba, 170p, 1993.

Joleaud. L: Etude géologique de la région de Bône et de la Calle-pub. Service carte géologique. Algérie n²12. 200p, 1936.

Lahondère, J.C.: La série ultra tellienne d'Algérie Nord orientale et les formations environnantes dans leur cadre structural. (Thèse de Doctorat d'état, Montpellier, 1987). 238p, 1987.

Laouar, R. et al.: Stable isotope study of the igneous, metamorphic and mineralized rocks of the Edough Complex, Annaba, north-east Algeria. Journal of African Earth Sciences, 35, 271-283, 2002.

Lekoui. S: Evaluation du risque lié aux sites pollués en milieu urbain et industriel, cas d'Annaba, Nord Est Algérien 176 p, 2010.

Louhi A. : Pollution des eaux et des sols. Cas de la région de Annaba, Etude des interférences et dosage de $\mathrm{Al}, \mathrm{Fe}, \mathrm{Cu}, \mathrm{Zn}, \mathrm{Ni}, \mathrm{Cr}, \mathrm{Pb}, \mathrm{Sn}, \mathrm{V}$ et $\mathrm{Hg}$ par 
spectrométrie d'émission Plasma-ARC (DCP-AES), absorption atomique (SAA) et spectrophotométrie UV/VIS. Th. Doctorat. Univ. Annaba, 167p, 1996.

Morin G. et Slivitzky M: Impacts des changements climatiques sur le régime hydrologique : Le cas de la rivière Moisie. Revue des Sciences de l'eau, vol. $5 \mathrm{~N}^{\circ} 02,179-195$. (1992.

Mudry J.: L'analyse discriminante, un puissant moyen de validation des hypothèses hydrogéologiques. Revue des Sciences de l’Eau, 4(1991), pp 1937, 1991.

Rouabhia. A, Baali. F, Kherici. N., Djabri. L: Vulnérabilité et impacts des activités anthropiques sur les eaux souterraines de la région d'El Ma EL Abiod. Revue vecteur environnement, Vol.37, N³, 2004.

Suresh TS, Naganna C, Srinivas G: Study of water quality for agricultural use in Hemavathy river (Karnataka). Hydrol $\mathrm{J}$ Indian Assoc Hydrol 14(4):247-254, 1991.

U.S. Salinity Laboratory Staff: Diagnosis and improvement of saline and alkali soils. Agric. Hand. No.60, USDA. U.S. Gov. Print. Off, Washington, D. C, 1954.

Vila .JM: Algerian mountain chain and the Algerian-Tunisian confines. Doctorate Thesis in Natural Sciences. University Pierre et Marie Curie, Paris 6, 1980.

Schoeller .H: Hydrodynamique dans le karst. Actes du colloque de Doubronik. IAHS/UNISCO, Wallingford, pp 3-15, 1965.

Wilcox .L: The quality of water for agriculture Tech Bull 962.Washington DC, 1948.

Zenati .N: Pollution de l'environnement aquatique : Diagnostic et Proposition. Région de Annaba ». Thèse de Doctorat en Géologie Appliquée, Université d’Annaba, 288p, 2010. 